\title{
Import-economic growth nexus in selected African countries: An application of the Toda-Yamamoto Granger non-causality test
}

\author{
Olufemi Adewale Aluko* \\ Adefemi A. Obalade ${ }^{* *}$
}

\begin{abstract}
We determine the nexus between imports and economic growth for a sample of 26 African countries for the period 1990-2015 within the neoclassical production function framework. We mainly contribute to literature by overcoming the weak theoretical modelling framework and possible model specification bias in most extant studies. Using the Toda-Yamamoto Granger non-causality test, the empirical results indicate that there is absence of causality between imports and economic growth in more than half of the countries in the sample, thus suggesting that neutrality hypothesis is predominant among the countries. We provide ample evidence that causality is absent from imports to economic growth. However, our results should be treated with caution because the absence of causality from imports to economic growth should not imply that imports do not play a role in the growth process of an economy.
\end{abstract}

Keywords: Imports; Economic growth; Toda-Yamamoto Granger non-causality test; Africa

JEL Classification: F10, F43, O11

\section{Introduction}

The raison d'être for imports is the lack of self-sufficiency inherent in virtually all countries. The theoretical basis for a country importing goods and services from another country lies in its inability to enjoy better relative production advantage. The theory of absolute advantage by Smith (1776) advocates that a country, say A, should import goods and services from another country, say B, if the latter can produce the goods and services more efficiently. On the other hand, the theory of comparative ad-

* Olufemi Adeyeye is at Department of Finance, University of Ilorin, Kwara State, Nigeria. Email: olufemiadewale6@gmail.com

** Adefemi A. Obalade is postdoctoral research fellow (Finance) at School of Accounting, Economics and Finance, University of KwaZulu-Natal, South Africa. Email: ObaladeA@stu.ukzn.ac.za. 
vantage propounded by Ricardo (1817) suggests that country A should import goods and services from country B if it does not possess a lower opportunity cost to produce the goods and services compared to country B. From an economic perspective, a country trades in imports to acquire intermediate production inputs for domestic production and finished goods for domestic consumption.

Imports introduce leakage in the circular flow of income and have been recognised as the primary cause of unemployment as opposed to economic growth (Liu et al., 1997). Hence, some countries protect local markets from competition with foreign producers. Nevertheless, imports are vital in the process of growth of a nation as indicated in the endogenous growth models. Compared with exports, Shan and Sun (1998) and Awokuse (2007) disclose that import plays a leading role in the growth of an economy. This is because imports are export-inducing and growth is export-induced (Awokuse 2008). The tendency of imports to drive economic growth also arises as local import-substituting companies compete with foreign counterpart from developed economies (Kim et al., 2007).

The choice of trade policy strategy requires an understanding of the nexus between import and economic growth. For instance, Helleiner (2007) opines that free trade (import liberalization) policy may not be suitable for the Third World countries whose goal is to expedite economic growth. Conversely, most Asian nations had to abrogate import substitution policy (protectionism) for import liberalization policy before they realise the advantages of imports (Nguyen, 2011). Furthermore, the import substitution policies implemented by majority of African countries were futile as a result of the great structural defects of their domestic markets and strong external resistance (Mendes et al., 2014).

Our aim is to examine the nexus between imports and economic growth in selected African countries. We examine the direction of causality between imports and economic growth for 26 countries in Africa in a time series modelling approach, thus supplementing the sparse empirical evidence on most of the selected countries. We contribute to literature in two ways. First, we provide causality evidence by incorporating imports into the neoclassical production function. Unlike most prior studies on African countries, the use of the neoclassical production function allows us to overcome possible weak theoretical modelling and reduce possible model specification bias. Van der Berg and Lewer (2015) argue that when only a trade variable is added to the basic sources of growth regression model and other relevant variables that engender economic growth are not included, it is likely that the model estimation method overestimates the effect of the trade variable. Majority of African empirical studies failed to use a theoretical growth model to establish the direction of causality between imports and economic growth. Secondly, we apply an augmented Granger non-causality test, which follows a standard asymptotic distribution and overcomes pretest biases relating to unit root and cointegration tests, hence providing valid statistical inferences. The application of this test to show the direction of causality be- 
tween imports and economic growth is limited in a large number of the selected countries. The remainder of this paper is as follows. The second section presents the literature review. The third section focuses on the methodology. The fourth section provides the empirical results and the last section gives the conclusion.

\section{Literature review ${ }^{1}$}

Vast and diverse empirical studies exist on the nexus between imports and economic growth at country, regional and international levels. These empirical studies suggest that four hypotheses can explain the nexus between imports and economic growth namely, import-led growth, growth-led import, feedback, and neutrality hypotheses. The import-led growth hypothesis asserts that the growth of an economy is caused by imports. It suggests that a unidirectional causality runs from imports to economic growth (Awokuse, 2008, 2007; Thangavelu \& Rajaguru, 2004; Din, 2004). On the contrary, the growth-led import hypothesis posits that economic growth causes imports. It suggests that a unidirectional causality moves from economic growth to imports (Chang et al., 2014; Liu et al., 2002). The feedback hypothesis argues that imports and economic growth cause each other. It posits that there is a bidirectional causality between imports and economic growth (Hye et al., 2013; Rahman \& Shahbaz, 2013; Zang \& Baimbridge, 2012). However, the neutrality hypothesis contends that imports and economic growth do not cause each other. It suggests that causality is non-existent between imports and economic growth (Thangavelu \& Rajaguru, 2004; Deme, 2002; Baharumshah \& Rashid, 1999). Following the discussion of the four hypotheses on imports-growth nexus is a comprehensive review of empirical studies.

In the South Asian context and employing the Toda-Yamamoto Granger causality test, Shirazi and Manap (2005) find a bidirectional causality between imports and economic growth in Bangladesh, Nepal, and Pakistan. The authors also find that there is unidirectional causality from imports to economic growth in Sri Lanka while in India, the unidirectional causality is from economic growth to imports. Similarly, Din (2004), using a VECM, show that there is bidirectional causality between imports and economic growth in Bangladesh and Pakistan while a unidirectional causality from economic growth to imports exists in India and Sri Lanka. For Nepal, a unidirectional causality from imports to economic growth is evident. Liu et al. (2002) employ the VECM Granger causality test to establish a unidirectional causal link from economic growth to imports in China between 1981Q1 and 1997Q4. Baharumshah and Rashid (1999), via the VECM, find that causality is absent between imports and economic growth in Malaysia over the quarterly period 1970Q1-1994Q4. Using the Sims causality test, Liu et al. (1997) find that there is bidirectional causality between imports and economic growth in China for the period 1983Q3-1995Q1. How- 
ever, the authors document the absence of causality between imports and economic growth with the application of the Geweke causality test.

Furthermore, Mishra, Sharma and Smyth (2010) find that bidirectional causality exists between imports and economic growth in the Pacific Island countries over the period 1982-2004, using a panel Granger causality test based on the pooled mean group estimator. Through a multivariate VAR analysis, Uğur (2008) document that, while unidirectional causality moves from economic growth to consumption goods imports and other goods imports, bidirectional causality exists between investment goods imports, raw material imports and economic growth in Turkey over the period 1994Q1-2005Q4. The author shows that there is bidirectional causality between total imports and economic growth. Çetintaş and Barişik (2009) employ the panel VECM Granger causality test to show that the causality between imports and economic growth is bidirectional for 13 transition countries for the period 1995Q2-2006Q4. Awokuse (2008), employing the error correction model (ECM)-based Granger causality test, records that there is bidirectional causality between imports and economic growth in Argentina and Colombia over the periods 1993Q1-2002Q2 and 1994Q12002Q2, respectively. The author also unearths a unidirectional causality from imports to economic growth in Peru during the period 1990Q1-2002Q2. By the same token, Awokuse (2007), relying on the ECM-based Granger causality test, discovers that a unidirectional causality from economic growth to imports exists in Bulgaria for the period 1994Q1-2004Q3. However, the unidirectional causality is from imports to economic growth in the Czech Republic and Poland for the periods 1993Q12002Q4 and 1995Q1-2004Q2, respectively. Tang (2006) demonstrates based on the ARDL modelling approach that a unidirectional causality from economic growth to imports exists in China during the period 1970-2001.

Relying on the Autoregressive Distributed Lag (ARDL) modelling approach, Hye (2012) observes a bidirectional causality between imports and economic growth in China over the period 1978-2009. Islam et al. (2012), using data for 62 countries for the period 1971-2009 and a modified Granger causality test, show that a unidirectional causality from imports to economic growth predominates in high-income countries while for low-income countries, there is a preponderance of bidirectional causality between imports and economic growth. Applying the VECM Granger causality test, Zang and Baimbridge (2012) find a bidirectional causality between imports and economic growth in South Korea and Japan during the periods 1963-2003 and 1957-2003, respectively. Based on the VAR Granger causality/Block Exogeneity test, Nguyen (2011) shows evidence of bidirectional causality between imports and economic growth in Malaysia between 1970 and 2004 and a unidirectional causality running from imports to economic growth in South Korea between 1976 and 2007. Using the Toda-Yamamoto Granger causality test, Kumari and Malhotra (2014) reveal that, while causality is not present between imports and economic growth in India between 1980 and 2012, the causality is bidirectional in China. Applying a modified Granger causality test, Hye et al. (2013) 
find a bidirectional causal link between imports and economic growth in 6 South Asian economies (Bangladesh, Bhutan, India, Nepal, Pakistan, and Sri Lanka). Rahman and Shahbaz (2013) utilize the Granger causality test based on a Vector Error Correction Model (VECM) to reveal that imports and economic growth cause each other in Pakistan between 1990 and 2010. This finding is supported by Shahbaz and Rahman (2012), using similar methodology.

In the context of African countries, Fapetu and Owoeye (2017), following the Toda-Yamamoto Granger causality testing procedure, show that imports cause economic growth with no feedback causality in Nigeria for the period 1981-2014. Bakari (2017) demonstrates with the aid of the VECM-based Granger causality test that there is a unidirectional causality moving from imports to economic growth in Egypt between 1965 and 2015. Using data for Mauritania for the period 1960-2015, Bakari and Krit (2017) reveal through the Granger causality test based on the VECM that a bidirectional causality is present between imports and economic growth. Andrews (2015), with the aid of the Pairwise Granger causality test, informs that a bidirectional causal relationship subsists between imports and economic growth in Liberia during the period 1970-2011. El Alaoui (2015) relies on the Granger causality test based on the VECM to reveal that the causality between imports and economic growth in Morocco over the period 1980-2013 is bidirectional. Chang et al. (2014) determine the causal link between imports and economic growth in 9 provinces of South Africa for the period 1996-2011 with the application of the bootstrap panel causality testing approach based on the seemingly unrelated regression estimation method. The results demonstrate the presence of unidirectional causality from economic growth to imports in 4 provinces. Also, whilst bidirectional causality exists in one province, causality is absent in the remaining 4 provinces. Within a VECM framework, Tsaurai (2012) tests for causality between imports and economic growth in Zimbabwe between 1980 and 2011 and finds a unidirectional causality from economic growth to imports. Hye and Boubaker (2011) employ the Autoregressive ARDL model to show that bidirectional causality is present between imports and economic growth in Tunisia between 1960 and 2008. Deme (2002) finds with the use of the VAR Granger causality test that there is no causality between imports and economic growth in Nigeria from 1970Q1-1997Q1.

\section{Methodology}

\section{Data and model}

Our analysis is based on annual data on gross domestic product (GDP) growth, gross capital formation (US dollar), labour force, and imports of goods and services (US dollar) for 26 African countries from 1990 to 2015, obtained from World's Bank 
World Development Indicators (WDI). The countries are selected based on data availability (see Tables 1 and 2 for the list of countries). GDP growth, gross capital formation, labour force, and import of goods and services proxy for economic growth $(\mathrm{Y})$, capital (K), labour (L), and imports (M) respectively. The data are used in their natural logarithm form except for GDP growth.

To determine the nexus between imports and economic growth, the neoclassical production function is augmented by incorporating imports. The augmented neoclassical production function is expressed as:

$$
Y=f(K, L, M)
$$

\section{Estimation approach}

We follow Toda and Yamamoto's (1995) Granger non-causality testing procedure, which is a modified Wald test for testing for long-run causality. ${ }^{2}$ This procedure does not require a pretest for cointegration and reduces biases in testing for causality with respect to power and sample size properties of unit root and cointegration tests (Zapata \& Rambaldi, 1997; Toda \& Yamamoto, 1995). The Toda and Yamamoto Granger non-causality test limits the problem associated with erroneously identifying the order of integration of time series and cointegration among time series by using the level form of the time series in the vector autogressive (VAR) model. It artificially augments the lag order of the VAR model by adding extra lag(s) informed by the maximum order of integration, $d_{\max }$ among the time series to the optimal lag length, $k$ (Wolde-Rufael, 2006). The addition of extra lag(s) to a VAR $(k)$ model ensures that the causality test is performed on the safer side if there is uncertainty regarding the order of integration of time series (Zapata \& Rambaldi, 1997). By estimating a $\left(k+d_{m a x}\right)^{\text {th }}$ order VAR model, the test statistic follows the standard asymptotic theory. The augmented neoclassical production is transformed into a $\operatorname{VAR}\left(k+d_{m a x}\right)$ model and it is expressed as:

$$
\begin{gathered}
Y_{t}=\alpha_{0}+\sum_{i=1}^{k} \alpha_{1 i} Y_{t-i}+\sum_{j=k+1}^{k+d_{\max }} \alpha_{2 j} Y_{t-j}+\sum_{i=1}^{k} \alpha_{3 i} \ln K_{t-i}+\sum_{j=k+1}^{k+d_{\max }} \alpha_{4 j} \ln K_{t-j}+\sum_{i=1}^{k} \alpha_{5 i} \ln L_{t-i} \\
+\sum_{j=k+1}^{k+d_{\max }} \alpha_{6 j} \ln L_{t-j}+\sum_{i=1}^{k} \alpha_{7 i} \ln M_{t-i}+\sum_{j=k+1}^{k+d_{\max }} \alpha_{8 j} \ln M_{t-j}+\varepsilon_{1 t} \\
\ln K_{t}=\beta_{0}+\sum_{i=1}^{k} \beta_{1 i} \ln K_{t-i}+\sum_{j=k+1}^{k+d_{\max }} \beta_{2 j} \ln K_{t-j}+\sum_{i=1}^{k} \beta_{3 i} Y_{t-i}+\sum_{j=k+1}^{k+d_{\max }} \beta_{4 j} Y_{t-j}+\sum_{i=1}^{k} \beta_{5 i} \ln L_{t-i} \\
+\sum_{j=k+1}^{k+d_{\max }} \beta_{6 j} \ln L_{t-j}+\sum_{i=1}^{k} \beta_{7 i} \ln M_{t-i}+\sum_{j=k+1}^{k+d_{\max }} \beta_{8 j} \ln M_{t-j}+\varepsilon_{2 t}
\end{gathered}
$$




$$
\begin{aligned}
\ln L_{t}=\delta_{0}+ & \sum_{i=1}^{k} \delta_{1 i} \ln L_{t-i}+\sum_{j=k+1}^{k+d_{\max }} \delta_{2 j} \ln L_{t-j}+\sum_{i=1}^{k} \delta_{3 i} Y_{t-i}+\sum_{j=k+1}^{k+d_{\max }} \delta_{4 j} Y_{t-j}+\sum_{i=1}^{k} \delta_{5 i} \ln K_{t-i} \\
& +\sum_{j=k+1}^{k+d_{\max }} \delta_{6 j} \ln K_{t-j}+\sum_{i=1}^{k+d_{\max }} \delta_{7 i} \ln M_{t-i}+\sum_{j=k+1}^{k} \delta_{8 j} \ln M_{t-j}+\varepsilon_{3 t} \ldots \text { (4) (4) } \\
\ln M_{t}=\phi_{0}+ & \sum_{i=1}^{k} \phi_{1 i} \ln M_{t-i}+\sum_{j=k+1}^{k+d_{\max }} \phi_{2 j} \ln M_{t-j}+\sum_{i=1}^{k} \phi_{3 i} Y_{t-i}+\sum_{j=k+1}^{k+d_{\max }} \phi_{4 j} Y_{t-j} \\
& +\sum_{i=1}^{k} \phi_{5 i} \ln K_{t-i}+\sum_{j=k+1}^{k} \phi_{6 j} \ln K_{t-j}+\sum_{i=1}^{k+d_{\max }} \phi_{7 i} \ln L_{t-i}+\sum_{j=k+1} \phi_{8 j} \ln L_{t-j} \\
& +\varepsilon_{4 t}
\end{aligned}
$$

\section{Empirical Results}

\section{Testing the order of integration}

In order to determine the order of integration of the time series, we employ the Augmented Dickey-Fuller (ADF) unit root test. The Schwarz information criterion is used to select the optimal lag length to perform the unit root test. The order of integration of the time series and $d_{\max }$ for each country are presented in Table 1 . The table shows that 7 countries (Kenya, Mali, Namibia, Senegal, Tanzania, Togo, and Uganda) have a $d_{\max }$ of 2 while the $d_{\max }$ for the remaining 19 countries is 1 .

Table 1: Order of integration

\begin{tabular}{|l|c|c|c|c|c|}
\hline Countries & $\mathrm{Y}$ & $\operatorname{lnK}$ & $\operatorname{lnL}$ & $\operatorname{lnM}$ & $d_{\max }$ \\
\hline Angola & $\mathrm{I}(1)$ & $\mathrm{I}(0)$ & $\mathrm{I}(1)$ & $\mathrm{I}(1)$ & 1 \\
\hline Benin & $\mathrm{I}(0)$ & $\mathrm{I}(0)$ & $\mathrm{I}(0)$ & $\mathrm{I}(1)$ & 1 \\
\hline Botswana & $\mathrm{I}(0)$ & $\mathrm{I}(1)$ & $\mathrm{I}(1)$ & $\mathrm{I}(1)$ & 1 \\
\hline Burundi & $\mathrm{I}(1)$ & $\mathrm{I}(1)$ & $\mathrm{I}(0)$ & $\mathrm{I}(1)$ & 1 \\
\hline Cameroon & $\mathrm{I}(0)$ & $\mathrm{I}(1)$ & $\mathrm{I}(0)$ & $\mathrm{I}(0)$ & 1 \\
\hline Congo Republic & $\mathrm{I}(0)$ & $\mathrm{I}(1)$ & $\mathrm{I}(0)$ & $\mathrm{I}(1)$ & 1 \\
\hline Egypt & $\mathrm{I}(0)$ & $\mathrm{I}(1)$ & $\mathrm{I}(1)$ & $\mathrm{I}(1)$ & 1 \\
\hline Gambia & $\mathrm{I}(0)$ & $\mathrm{I}(1)$ & $\mathrm{I}(0)$ & $\mathrm{I}(1)$ & 1 \\
\hline Ghana & $\mathrm{I}(0)$ & $\mathrm{I}(1)$ & $\mathrm{I}(0)$ & $\mathrm{I}(1)$ & 1 \\
\hline Guinea-Bissau & $\mathrm{I}(0)$ & $\mathrm{I}(1)$ & $\mathrm{I}(0)$ & $\mathrm{I}(1)$ & 1 \\
\hline Kenya & $\mathrm{I}(0)$ & $\mathrm{I}(1)$ & $\mathrm{I}(2)$ & $\mathrm{I}(1)$ & 2 \\
\hline Madagascar & $\mathrm{I}(0)$ & $\mathrm{I}(1)$ & $\mathrm{I}(1)$ & $\mathrm{I}(1)$ & 1 \\
\hline Malawi & $\mathrm{I}(0)$ & $\mathrm{I}(0)$ & $\mathrm{I}(0)$ & $\mathrm{I}(1)$ & 1 \\
\hline Mali & $\mathrm{I}(0)$ & $\mathrm{I}(1)$ & $\mathrm{I}(2)$ & $\mathrm{I}(1)$ & 2 \\
\hline
\end{tabular}


Table 1 - Continued

\begin{tabular}{|l|c|c|c|c|c|}
\hline Countries & $\mathrm{Y}$ & $\operatorname{lnK}$ & $\operatorname{lnL}$ & $\operatorname{lnM}$ & $d_{\max }$ \\
\hline Mauritius & $\mathrm{I}(0)$ & $\mathrm{I}(1)$ & $\mathrm{I}(1)$ & $\mathrm{I}(1)$ & 1 \\
\hline Morocco & $\mathrm{I}(0)$ & $\mathrm{I}(1)$ & $\mathrm{I}(0)$ & $\mathrm{I}(1)$ & 1 \\
\hline Namibia & $\mathrm{I}(0)$ & $\mathrm{I}(0)$ & $\mathrm{I}(2)$ & $\mathrm{I}(1)$ & 2 \\
\hline Nigeria & $\mathrm{I}(0)$ & $\mathrm{I}(1)$ & $\mathrm{I}(1)$ & $\mathrm{I}(1)$ & 1 \\
\hline Senegal & $\mathrm{I}(0)$ & $\mathrm{I}(1)$ & $\mathrm{I}(2)$ & $\mathrm{I}(1)$ & 2 \\
\hline Sierra Leone & $\mathrm{I}(0)$ & $\mathrm{I}(1)$ & $\mathrm{I}(0)$ & $\mathrm{I}(1)$ & 1 \\
\hline South Africa & $\mathrm{I}(0)$ & $\mathrm{I}(1)$ & $\mathrm{I}(1)$ & $\mathrm{I}(1)$ & 1 \\
\hline Swaziland & $\mathrm{I}(0)$ & $\mathrm{I}(1)$ & $\mathrm{I}(1)$ & $\mathrm{I}(1)$ & 1 \\
\hline Tanzania & $\mathrm{I}(0)$ & $\mathrm{I}(1)$ & $\mathrm{I}(2)$ & $\mathrm{I}(1)$ & 2 \\
\hline Togo & $\mathrm{I}(0)$ & $\mathrm{I}(0)$ & $\mathrm{I}(2)$ & $\mathrm{I}(1)$ & 2 \\
\hline Tunisia & $\mathrm{I}(0)$ & $\mathrm{I}(1)$ & $\mathrm{I}(0)$ & $\mathrm{I}(1)$ & 1 \\
\hline Uganda & $\mathrm{I}(0)$ & $\mathrm{I}(1)$ & $\mathrm{I}(2)$ & $\mathrm{I}(1)$ & 2 \\
\hline
\end{tabular}

\section{Testing for causality}

Due to the number of observations, we set the maximum lag order of the VAR model to be 3 and use two information criteria namely Akaike information criterion (AIC) and Schwarz information criterion (SIC) to determine the optimal lag length, $k{ }^{3}$ The Lagrange Multiplier (LM) test is utilized to confirm that the $k$ is one that makes the residuals in the VAR model to be serially uncorrelated. Table 2 reports the results of the Toda and Yamamoto Granger non-causality tests.

As reported in Table 2, the unidirectional causality runs from imports to economic growth in Angola, Mauritius, and Tunisia, implying that economic growth is import-driven in these countries. It implies that imports spur economic growth in these countries, and thus import is beneficial. In this context, trade liberalisation policy such as removal of quotas or reduction of charges and several customs duty exemptions on imported inputs may be a step in the right direction. It is, however, important to identify the components of imports that contribute to growth in these countries.

In addition, Table 2 shows a unidirectional causality moving from economic growth to imports in Burundi, Congo Republic, Ghana, Kenya, Mali, South Africa, and Togo. This implies that economic growth causes a shift in demand for imports in these countries. Countries in this category are better poised to enjoy free trade with rest of the world, however, they must be cautious as imports could introduce leakage in the circular flow of income and cause unemployment (Liu et al., 1997).

Bidirectional causality between imports and economic growth is found for Swaziland only. This implies that imports and economic growth cause each other. It means that growth is both import-inducing and import-induced, which is supportive of the feedback hypothesis. In this context, dual goals of implementing trade policies that accelerate growth and import must be pursed simultaneously. Lastly, results show 
that there is no causality between imports and economic growth in the remaining 15 countries, thus indicating that imports and economic growth do not drive each other which is in support of import neutrality hypothesis. Therefore, these countries may pursue import liberalisation programmes as there may be no reason to restrict trade.

Table 2: Toda and Yamamoto Granger non-causality tests

\begin{tabular}{|c|c|c|c|c|c|}
\hline \multirow[b]{2}{*}{ Countries } & \multirow[b]{2}{*}{$k$} & \multirow[b]{2}{*}{$k+d_{\max }$} & \multicolumn{2}{|c|}{ Direction of causality } & \multirow[b]{2}{*}{ Causality inference } \\
\hline & & & $\mathrm{M} \rightarrow \mathrm{Y}$ & $\mathrm{Y} \rightarrow \mathrm{M}$ & \\
\hline Angola & 3 & 4 & Present & Absent & Unidirectional $^{\mathrm{a}}$ \\
\hline Benin & 3 & 4 & Absent & Absent & No causality \\
\hline Botswana & 2 & 3 & Absent & Absent & No causality \\
\hline Burundi & 3 & 4 & Absent & Present & Unidirectional $^{\mathrm{b}}$ \\
\hline Cameroon & 3 & 4 & Absent & Absent & No causality \\
\hline Congo Republic & 2 & 3 & Absent & Present & Unidirectional $^{\mathrm{b}}$ \\
\hline Egypt & 1 & 2 & Absent & Absent & No causality \\
\hline Gambia & 1 & 2 & Absent & Absent & No causality \\
\hline Ghana & 3 & 4 & Absent & Present & Unidirectional $^{\mathrm{b}}$ \\
\hline Guinea-Bissau & 3 & 4 & Absent & Absent & No causality \\
\hline Kenya & 2 & 4 & Absent & Present & Unidirectional $^{\mathrm{b}}$ \\
\hline Madagascar & 3 & 4 & Absent & Absent & No causality \\
\hline Malawi & 3 & 4 & Absent & Absent & No causality \\
\hline Mali & 2 & 4 & Absent & Present & Unidirectional $^{\mathrm{b}}$ \\
\hline Mauritius & 2 & 3 & Present & Absent & Unidirectional $^{\mathrm{a}}$ \\
\hline Morocco & 3 & 4 & Absent & Absent & No causality \\
\hline Namibia & 2 & 4 & Absent & Absent & No causality \\
\hline Nigeria & 1 & 2 & Absent & Absent & No causality \\
\hline Senegal & 2 & 4 & Absent & Absent & No causality \\
\hline Sierra Leone & 2 & 3 & Absent & Absent & No causality \\
\hline South Africa & 2 & 3 & Absent & Present & Unidirectional $^{\mathrm{b}}$ \\
\hline Swaziland & 3 & 4 & Present & Present & Bidirectional \\
\hline Tanzania & 1 & 3 & Absent & Absent & No causality \\
\hline Togo & 1 & 3 & Absent & Present & Unidirectional $^{\mathrm{b}}$ \\
\hline Tunisia & 1 & 2 & Present & Absent & Unidirectional $^{\mathrm{a}}$ \\
\hline Uganda & 2 & 4 & Absent & Absent & No causality \\
\hline
\end{tabular}

\section{Conclusion}

We follow the Toda and Yamamoto (1995) Granger non-causality testing procedure to determine the nexus between imports and economic growth in 26 countries in Africa within an augmented neoclassical production function. We find evidence to support the four hypotheses on the possible nexus between imports and econom- 
ic growth. There is unidirectional causality running from imports and economic growth in 3 countries and this is consistent with the import-led growth hypothesis. Unidirectional causality from economic growth to imports is present in 7 countries, thus lending support for the growth-led import hypothesis. Bidirectional causality between imports and economic growth is evident in only one country and this is supportive of the feedback hypothesis. There is absence of causality between imports and economic growth in 15 countries, thus conforming to the neutrality hypothesis. The neutrality hypothesis is valid for more than $50 \%$ of the countries, thus suggesting that it is predominant among the countries in the sample. We provide evidence that causality is absent from imports to economic growth in 22 countries. However, our results should be treated with caution because the absence of causality from imports to economic growth should not imply that imports do not play a role in the growth process of an economy.

\section{NOTES}

${ }^{1}$ Some studies provide evidence on the direction of causality between imports and economic growth in a multivariate vector autogressive model, particularly while controlling for imports in testing the export-led growth hypothesis (see Awokuse, 2008, 2007; Din, 2004; Baharumshah \& Rashid, 1999; Shan and Sun, 1998; Riezman et al., 1996).

2 Toda and Yamamoto (1995) Granger non-causality testing procedure overcomes the weaknesses of the traditional Granger non-causality tests. For weaknesses of traditional Granger non-causality tests, see Zapata and Rambaldi (1997) and Toda and Yamamoto (1995).

${ }^{3} k$ is the lag length that minimizes either AIC or SIC.

\section{REFERENCES}

Amiri, A., and Gerdtham, U. (2011). Relationship between exports, imports, and economic growth in France: Evidence from cointegration analysis and Granger causality with using geostatistical models. MPRA Paper No. 34190. Munich University Library. Germany.

Andrews, A. P. (2015). Exports, imports and economic growth in Liberia: Evidence from causality and cointegration analysis. Journal of Management Policy and Practice, 16(3), 95-109.

Awokuse, T. O. (2008). Trade openness and economic growth: Is growth export-led or import-led? Applied Economics, 40(2), 161-173.

Awokuse, T. O. (2007). Causality between exports, imports, and economic growth: Evidence from transition economies. Economic Letters, 94(3), 389-395.

Baharumshah, A. Z., \& Rashid, S. (1999). Exports, imports and economic growth in Malaysia: Empirical evidence based on multivariate time series. Asian Economic Journal, 13(4), 389-406.

Bakari, S. (2017). The relationship between export, import, domestic investment and economic growth: Empirical analysis. EuroEconomica, 36(2), 34-43.

Bakari, S., \& Krit, M. (2017). The nexus between exports, imports and economic growth: Evidence from Mauritania. International Journal of Economics and Empirical Research, 5(1), 10-17. 
Çetintaş, H., \& Barişik, S. (2009). Export, import and economic growth: The case of transition economies. Transition Studies Review, 15(4), 636-649.

Chang, T., Simo-Kengne, B. D., \& Gupta, R. (2014). The causal relationship between imports and economic growth in nine provinces of South Africa: Evidence from panel Granger causality tests. Journal of Economic Cooperation and Development, 35(2), 71-90.

Deme, M. (2002). An examination of the trade-led growth hypothesis in Nigeria: A co-integration, causality, and impulse response analysis. The Journal of Developing Areas, 36(1), 1-15.

Din, M. (2004). Exports, imports and economic growth in South Asia: Evidence using a multivariate time-series framework. The Pakistan Development Review, 43(2), 105-124.

El Alaoui, A. (2015). Causality and cointegration between export, import and economic Growth: Evidence from Morocco. Journal of World Economic Research, 4(3), 83-91. doi: 10.11648/j. jwer.20150403.14

Fapetu, O., \& Owoeye, S. D. (2017). Testing the validity of the export-led growth hypothesis in Nigeria: Evidence from non-oil and oil exports. Computational Methods in Social Sciences, 5(2), 41-48.

Helleiner, G. K. (2007). Structural aspect of Third World trade: Some trends and some prospects. Journal of Development Studies, 15(3), 70-88.

Hye, Q. M. A., \& Boubaker, H. B. H. (2011). Exports, imports and economic growth: An empirical analysis of Tunisia. IUP Journal of Monetary Economics, 9(1), 6-21.

Hye, Q. M. (2012). Exports, Imports and Economic Growth in China: An ARDL Analysis. Journal of Chinese Economic and Foreign Trade Studies, 4 (1), 42-55.

Hye, Q. M. A., Wizarat, S., \& Lau, W. (2013). Trade-led growth hypothesis: An empirical analysis of South Asian countries. Economic Modelling, 35, 654-660.

Kim, S., Lim, H., \& Park, D. (2007). Could imports be beneficial for economic growth? Some evidence from Republic of Korea. ERD Working Paper No. 103.

Kumari, D., \& Malhotra, N. (2014). Trade-led growth in India and China: A comparative analysis. Journal of International and Global Economic Studies, 7(2), 68-88.

Liu, X., Burridge, P., \& Sinclair, P. J. (2002). Relationships between economic growth, foreign direct investment and trade: Evidence from China. Applied Economics, 34(11), 1433-1440.

Liu, X., Song, H., \& Romilly, P. (1997). An empirical investigation of the causal relationship between openness and economic growth in China. Applied Economics, 29(12), 1679-1686.

Mendes, A. P. F., Bertella, M. A., \& Teixeira, R. F. (2014). Industrialization in sub-Saharan Africa and import substitution policy. Revista de Economica Política, 34(1), 120-138.

Mishra, P. K. (2012). The dynamics of the relationship between imports and economic growth in India. South Asian Journal of Macroeconomics and Public Finance, 1(1), 57-79.

Mishra, V., Sharma, S. S., \& Smyth, R. (2010). Is economic development in the Pacific island countries export-led or import-led? Pacific Economic Bulletin, 25(1), 46-63.

Moroke, N. D., \& Manoto, M. (2015). How applicable is export-led growth and import-led growth hypotheses to South African economy? The VECM and causality approach. Journal of Governance and Regulation, 4(2), 15-25.

Nguyen, H. T. (2011). Exports, imports, FDI and economic growth. Working Paper No. 11-03.

Rahman, M. M., \& Shahbaz, M. (2013). Do imports and foreign capital inflows lead economic growth? Cointegration and causality analysis in Pakistan. South Asia Economic Journal, 14(1), 59-81.

Ricardo, D., 1817. On the principles of political economy and taxation. London: John Murray.

Riezman, R. G., Summers, P. M., \& Whiteman, C. H. (1996). The engine of growth or its handmaiden? A time series assessment of export-led growth. Empirical Economics, 21(1), 77-113.

Shan, J., \& Sun, F. (1998). On the export-led growth hypothesis: The econometric evidence from China. Applied Economics, 30(8), 1055-1065. 
Shahbaz, M., \& Rahman, N. M. (2012). The dynamic of financial development, imports, foreign direct investment and economic growth: Cointegration and causality analysis in Pakistan. Global Business Review, 13(2), 65-82.

Shirazi, N. S., \& Manap, T. A. A. (2005). Exports-led growth hypothesis: Further econometric evidence from South Asia. The Developing Economies, XLIII(4), 472-488.

Smith, A. (1776). An inquiry into the nature and causes of the wealth of nations. London: W. Strahan and T. Cadell.

Tang T. C. (2006). New evidence on export expansion, economic growth and causality in China. Applied Economics Letters, 13, 801-803.

Thangavelu, S. M., \& Rajaguru, G. (2004). Is there an export or import-led productivity growth in rapidly developing Asian countries? A multivariate VAR analysis. Applied Economics, 36(10), 1083-1093.

Toda, H. Y., \& Yamamoto, T. (1995). Statistical inference in vector autoregressions with possibly integrated processes. Journal of Econometrics, 66(1-2), 225-250.

Tsaurai, K. (2012). A dynamic causality test of imports and economic growth in Zimbabwe. International Journal of Economic Policy in Emerging Economies, 5(3), 243-254.

Ugur, A. (2008). Import and Economic Growth in Turkey: Evidence from Multivariate VAR Analysis. East-West Journal of Economics and Business , 11(1-2), 54-75.Van der Berg, H., \& Lewer, J. J. (2015). International trade and economic growth. London: Routledge.

Wolde-Rufael, Y. (2006). Electricity consumption and economic growth: A time series experience for 17 African countries. Energy Policy, 34(10), 1106-1114.

Zang, W., \& Baimbridge, M. (2012). Exports, imports and economic growth in South Korea and Japan: A tale of two economies. Applied Economics, 44(3), 361-372.

Zapata, H. O., \& Rambaldi, A. N. (1997). Monte Carlo evidence on cointegration and causation. Oxford Bulletin of Economics and Statistics, 59(2), 285-298. 